Inequalities of Love 
POLITICS, HISTORY, AND CULTURE

A series from the International Institute at the University of Michigan

Series Editors

George Steinmetz and Julia Adams

Series Editorial Advisory Board

Fernando Coronil

Nancy Rose Hunt

Julie Skurski

Mamadou Diouf

Andreas Kalyvas

Margaret Somers

Michael Dutton

Webb Keane

Ann Laura Stoler

Geoff Eley

David Laitin

Katherine Verdery

Fatma Müge Göcek

Lydia Liu

Elizabeth Wingrove

Sponsored by the International Institute at the University of Michigan and published by Duke University Press, this series is centered around cultural and historical studies of power, politics, and the state - a field that cuts across the disciplines of history, sociology, anthropology, political science, and cultural studies. The focus on the relationship between state and culture refers both to a methodological approach - the study of politics and the state using culturalist methods and a substantive one that treats signifying practices as an essential dimension of politics. The dialectic of politics, culture, and history figures prominently in all the books selected for the series. 


\section{INEQUALITIES OF LOVE}

College-Educated Black Women and the Barriers to Romance and Family

\section{AVERIL Y. CLARKE}

DUKE UNIVERSITY PRESS

Durham \& London 2011 
(c) 2011 Averil Y. Clarke

All rights reserved

Printed in the United States of America on acid-free paper @

Designed by Jennifer Hill

Typeset in Adobe Warnock Pro by Tseng Information Systems, Inc.

Library of Congress Cataloging-in-Publication Data

appear on the last printed page of this book. 
For Mom, Dad, Greer, Hilton, Aunty, and those you have made my family-

Rachel, Domi, Kyle, Jordy, Courtney,

Jonas and Drew 
